\title{
Uniwersytet jako przestrzeń modulacji i molekularnego oporu
}

Jednym z celów, jakie w swojej najnowszej książce postawił przed sobą Gerald Raunig, austriacki filozof związany z wielojęzycznym projektem transversal, jest próba konceptualnego przepracowania metafor związanych z produkcją wiedzy i kultury w warunkach obecnego etapu rozwoju kapitalizmu. Pierwszą z nich jest „fabryka”, omawiana w kontekście współczesnych transformacji uniwersytetu, drugą "przemys” odniesiony do hegemonii przemystów kulturalnych i kreatywnych. Koncentruje się zatem na sektorach, w których obecnie w kapitalizmie kognitywnym lokowane są procesy pomnażania wartości. Książkę należy postrzegać jako kontynuację $A$ Thousand Machines ${ }^{1}$, w której Raunig na kolejnych obszarach ${ }^{2}$ usiłował opracować pojęcie-klucz - rozumianą za Felixem Guattarim maszynę - spinające również jego rozważania $\mathrm{z}$ Factories of Knowledge.

Choć rację ma Roberto Nigro, którego nota została dołączona na okładce, że książkę Rauniga można odczytywać na przynajmniej trzech poziomach (analizy współczesnych ruchów społecznych, problematyki pracy

1 G. Raunig, A Thousands Machines, Los Angeles 2011.

2 Mamy tu zatem do czynienia z błyskotliwą analizą Fragmentu o maszynach Marksa, maszyny teatru, maszyn wojennych Deleuza i Guattariego, maszyny społecznej prekariackich protestów czy wreszcie pojawiającej się często na kartach Factories of Knowledge abstrakcyjnej maszyny. 
i produkcji w sferze kultury i nauki, oraz radykalnej krytyki polityki reprezentacyjnej), to z racji zainteresowań badawczych w mojej krótkiej recenzji chciałbym dokonać pewnego zawężenia pola. Przeanalizuję zatem przede wszystkim sposoby ujmowania zmian zachodzących w sektorze szkolnictwa wyższego oraz konceptualizacji oporu, jaki może zrodzić się w murach instytucji uniwersytetu, które austriacki filozof kreśli przede wszystkim w pierwszej części swojej książki.

\section{Krytyczne badania nad szkolnictwem wyższym i tendencje rozwojowe w sektorze uniwersyteckim}

Interesującą mnie część propozycji Rauniga można wpisać w szerszy nurt rozważań poświęconych instytucji uniwersytetu. Podobnie jak Jeffrey Williams, określam je mianem krytycznych badań nad szkolnictwem wyższym ${ }^{3}$. Badania te, wyrosłe przede wszystkim na fali krytyki dotyczącej korporatyzacji uniwersytetu czy formowania się kapitalizmu akademickiego w latach dziewięćdziesiątych, współcześnie podejmują wiele różnorodnych problemów: od proletaryzacji i prekaryzacji pracowników akademickich, przez kwestie długu i form uzwiązkowienia w epoce menadżeryzmu oraz studenckiego oporu, aż po miejsce i funkcje uniwersytetu w ramach przechodzenia do epoki kapitalizmu kognitywnego. Tę perspektywę badawczą przyjmuje coraz więcej badaczy i badaczek ${ }^{4}$. Raunig, podobnie jak związany z kolektywen Edu-factory Gigi Roggero5, choć głęboko zadłużony w myśli post-operaistycznej i skupiający swoje zainteresowanie uniwersytetem na kwestiach walki,

3 J.J. Williams, Dekonstrukcja Akademii: Narodziny krytycznych badań nad uniwersytetem, tłum P. Kowzan, M. Zielińska, http://www.praktykateoretyczna. $\mathrm{pl} /$ jeffrey-j-williams-dekonstrukcja-akademii-narodziny-krytycznych-badan-naduniwersytetem/

4 Choć trzeba przyznać, że pomimo sukcesywnego instytucjonalizowania dziedziny (w 2013 roku ruszyła pierwsza seria wydawnicza pod kierownictwem Jeffreya Williamsa i Christophera Newfielda) jest to obszar badań szkolnictwa wyższego, w którym dominują badacze pierwszego typu (discipline-based, occasional higher education researchers) wyróżnionego przez Ulricha Teichlera, cechujący się bardzo dobrym zapleczem metodologicznym i teoretycznym, słabą wiedzą dotycząca obszaru badania oraz niewielkim potencjałem, jeśli chodzi zastosowanie praktyczne formułowanych propozycji, zob. U. Teichler, Research on Higher Education in Europe, "European Journal of Education" 2005, nr 4, s. 460.

5 Zob. G. Roggero, The Production of Living Knowledge, ttum. E. Brophy, Philadelphia 2012. Zob. również kontekstową analizę tej książki: K. Szadkowski, Kryzys uniwersytetu i rewolta żywej wiedzy, „Praktyka Teoretyczna” 2012, nr 6, s. 391-403. 
oporu oraz tworzenia alternatywy dla kapitalistycznego status quo, poświęcił nieco miejsca na analizę współczesnych transformacji sektora szkolnictwa wyższego.

W tym właśnie kontekście ciekawą propozycją jest jego próba „uporządkowania” tendencji transformacji współczesnego uniwersytetu w postaci listy zawierającej dwadzieścia osiem tez ${ }^{6}$. Uwaga Rauniga wydaje się jednak mocno rozproszona, a na konkretnych problemach skupiania niekiedy w sposób wydawałoby się całkiem przypadkowy. Jeśli chcielibyśmy wykroczyć z tego chaosu ku porządkowi, należałoby ułożyć te listę według zagadnień oraz ilości poświęcanego im w książce miejsca. W takim układzie na pierwszy plan wysuwa się kwestia miary i pomiaru w sektorze szkolnictwa wyższego, którą na potrzeby niniejszej recenzji moglibyśmy nazwać mutacją „prawa wartości”. Wszechogarniający, standaryzujący i hierarchizujący wszystko system pomiaru wydaje się głównym przedsięwzięciem „modulującego uniwersytetu” (1) ${ }^{7}$. Składają się na niego znane nam z polskiej rzeczywistości elementy: punkty za zajęcia, rankingi uniwersytetów, współczynniki wpływu, punkty za publikacje, ewaluacja czasopism naukowych, wskaźniki produktywności kadry i jednostek naukowych. Wszystko to służy wyznaczaniu wartości, zarówno siły roboczej pracowników, jak i towaru oferowanego przez konkretne instytucje edukacyjne (2), które następnie przekształcane są w płace i ceny. Miara w kontekście pracy akademickiej ma charakter biopolityczny, a pomiarowi i wycenie podlega cała aktywność życiowa pracowników, określana eufemistycznie trajektorią kariery akademickiej, na którą składać się mają przede wszystkim liczone w punktach i liczbie cytowań aktywności publikacyjne (12). Natomiast podporządkowane pomiarowi i imperatywowi efektywności aktywności badawczej i publikacyjnej odziera ją ze znaczenia, skupiając się wyłącznie wskaźnikach finansowych oraz publikacyjnych (11). Koncentracja na wyrabianiu konkretnych osiągnięć dających się ująć w kategoriach statystycznych poddaje według Rauniga represji wszelką kreatywność niemieszczącą się w wąkich okach sieci pomiaru (19). Sprowadzenie zarówno aktywności naukowej i dydaktycznej, jak i życia pracujących na uniwersytecie indywiduów do zestandaryzowanych jednostek sprzyja rozpowszechnianiu się w sektorze szkolnictwa wyższego strategii benchmarkingu (18),

6 G. Raunig, Factories of Knowledges, Industries of Creativity, thum. A. Derie, posł. A. Negri, Los Angeles 2013, s. 29-39. Raunig formułuje również podobną, choć krótszą, listę siedemnastu tendencji w kontekście współczesnych przemian kreatywności, zob. tamże, s. 105-109.

7 W dalszej części tego fragmentu będę posługiwał się nawiasami zawierającymi numery kolejnych spośród dwudziestu ośmiu tendencji zebranych przez Rauniga. 
Pomiar i oparty

na nim proces

wyznaczania wartości

jest dla produkcji

podporządkowanej

zasadzie kapitału

rzeczą konstytutywną

i podkreślenie jego

fundamentalnego

znaczenia oraz

konsekwencji dla

współczesnego

uniwersytetu jest

zdecydowanie poważną zasługą Rauniga w którym specjalizują się liczne firmy kosnultingowe i te zajmujące się audytem oraz ewaluacją $(23)^{8}$. Pomiar i oparty na nim proces wyznaczania wartości jest dla produkcji podporządkowanej zasadzie kapitału rzeczą konstytutywną i podkreślenie jego fundamentalnego znaczenia oraz konsekwencji dla współczesnego uniwersytetu jest zdecydowanie poważną zasługą Rauniga.

Autor $A$ Thousands Machines schodzi jednak o poziom głębiej, przyglądając się bezpośrednim konsekwencjom dla podporządkowanej naukowemu przemysłowi publikacyjnemu formy akademickiego pisania. Mamy zatem do czynienia przede wszystkim z uniformizacją stylu i formy (13), podporządkowaniem treści i politycznego stanowiska refleksji metodologicznej (14), połączonych z hegemonią języka angielskiego, dławiącego według Rauniga elementy zróżnicowanej kulturowo ekspresji właściwej innym tradycjom i językom narodowym (16). Wszystko to natomiast odbywa się w ramach systemu recenzowanych czasopism stających się współczesnymi narzędziami inkluzji i eksluzji w środowiskach naukowych (15).

Raunig zwraca uwagę również na szereg innych kwestii. Podkreśla właściwą kapitałowi, próbującemu umknąć konsekwencjom nadprodukcji i związanym z nią kryzysom, tendencję do tworzenie rynku światowego i przekraczania wszelkich barier, przede wszystkim geograficznych, w celu rozszerzania produkcji edukacyjnej na skalę globalną $(27,28)$. Uwypukla znaczenie kwestii zadłużenia studenckiego $(3,4)$ czy stopniowego „dostosowywania” dydaktyki do potrzeb rynku pracy czy badań do zapotrzebowania przemysłu $(6,21)$. Wszystko to przy towarzyszącym pozornym wycofywaniu się państwa z sektora szkolnictwa wyższego i stosowania przez administrację publiczną bardziej „otwartych” metod koordynacji systemów i ukierunkowywania ich prorynkowo $(24,25)^{9}$.

Co jednak z tego wszystkiego miałoby wynikać? Raunig ani nie tworzy żadnej spójnej narracji z tych dość powierzchownych wypisów i wyliczanki cech dominacji logiki kapitału w sektorze szkolnictwa wyższego,

8 W kontekście polskim warto zwrócić uwagę na mało transparentną rolę, jaką odegrała (i nadal odgrywa) firma Index Copernicus w procesie powstawania systemu ewaluacji czasopism naukowych oraz tworzenia bazy danych o polskim systemie szkolnictwa wyższego i nauki POLON w trakcie fali reform 2008-2012. W kontekście strategii benchmarkingu i audytu w gospodarce wiedzy zob. I. Bruno, Zarzadzanie spoteczna kreatywnościa przez benchmarking: Od menadżmentu Xeroxa do „Innowacyjnej Europy”, tłum. A. Wojczyńska, w: Wiecznna radośc: Ekonomia polityczna spotecznej kreatywności, red. M. Kozłowski, A. Kurant, J. Sowa, K. Szadkowski, K. Szreder, Warszawa 2011, s. 239-255.

9 Zob. K. Czarnecki, Nowe Zarzadzanie Publiczne a reforma szkolnictwa wyższego w Polsce, „Praktyka Teoretyczna” 2013, nr 1, s. 85-106. 
ani nie wyprowadza żadnych konkretnych wniosków. Spostrzeżenia towarzyszące wskazaniu tych tendencji nie są również ani zbyt odkrywcze, gdyż do każdej z wymienionych można by przyporządkować długą listę analiz i artykułów problematyzujących te kwestie, ani zbyt pogłębione. Natomiast samo zestawienie ich razem nie tworzy żadnej szczególnie godnej uwagi wartości dodanej. Pod tym względem rozważania Rauniga są niesatysfakcjonujące i do pewego stopnia rozczarowujące. Jednak podstawowym celem autora niestety nie jest analityczna wykładnia współczesnych transformacji szkolnictwa wyższego. Więcej jasności w tej kwestii możemy uzyskać, przyglądając się jego podejściu do tytułowej kategorii fabryki.

\section{Od metafory do pojęcia. Funkcjonalność i ograniczenia perspektywy fabryki wiedzy}

Spoglądanie na instytucje edukacyjne przez pryzmat metafory fabryki posiada swoją długą historię. Już Marks w Kapitale, próbując dostarczyć przykładów tego, że praca w warunkach produkcji kapitalistycznej nie jest tylko wytwarzaniem materialnych towarów, a polega przede wszystkim na wytwarzaniu wartości dodatkowej dla kapitalisty, sięga po przykład ze sfery produkcji niematerialnej, odnosząc się do pracy nauczyciela - produkcyjnego pracownika prywatnej fabryki wiedzy.

W 1909 roku pozorne podobieństwo rozrastającego się MIT do rozkwitających podówczas fabrycznych zakładów przemysłowych skłoniło ówczesnego rektora, Henry'ego S. Pritchetta do sięgnięcia po metody Taylorowskiego zarządzania. W tym miejscu metafora rzeczywiście służyła za wzorzec, pod który przykrojona miała zostać rzeczywista praktyka zarządzania uniwersytetem. Morris L. Cook, uczeń Taylora, w kilka miesięcy sporządził pokaźny raport na temat podobieństw i różnic w przemysłowych i akademickich metodach zarządzania efektywnością pracy, udzielając wielu rekomendacji i zaleceń przyszłym menadżerom uczelni. Jednakże wyniki badania i analizy przeprowawadzone przez Cooka nigdy nie zostały wcielone w życie ${ }^{10}$.

Rok 1968 to moment, w którym ruchy studenckie na całym świecie zaczęły posługiwać się metaforą uniwersytetu-fabryki w celu demaskacji odczłowieczających stosunków panujących na współczesnych uczelniach. Przywoływany w książce przez Rauniga rysunek Gerharda Seyfrie-

10 Zob. M.L. Cook, Academic and Industrial Efficiency: A Report to the Carnegie Foundation for the Advancement of Teaching, New York 1910.
Pod tym względem

rozważania Rauniga

są niesatysfakcjonujące

i do pewego stopnia

rozczarowujące. Jednak podstawowym celem

autora niestety nie jest

analityczna wykładnia

współczesnych

transformacji

szkolnictwa wyższego 
$\mathrm{da}^{11}$ doskonale oddaję atmosferę, w której ówcześnie uprawiano krytykę. Uniwersytet miał być masową fabryką dyplomów oraz sformatowanych i zunifikowanych, podatnych na formowanie przez miejsce pracy studentów. Rozpoznanie fabrycznego czy wręcz maszynowego charakteru uczelni przełożyło się na praktyki oporu. Skoro uniwersytet działa jak fabryka, to możliwe jest zatrzymanie jego trybów, strajk czy okupacyjne przejęcie kontroli. Jak wiele lat później stwierdził Harry Cleaver, uniwersytet-fabryka miałby być podobny w pewnym sensie do innych fabryk, a marksistowskie analizy mogą stać się przydatne w jego zrozumieniu ${ }^{12}$.

Jednak to oczywiście nie koniec historii tej nośnej metafory. W ostatnim czasie najgłośniejszy użytek uczynił z niej międzynarodowy kolektyw Edu-factory ${ }^{13}$, pytając o to: czy tym, czym kiedyś dla kapitalizmu przemysłowego była fabryka, dziś dla kapitalizmu kognitywnego jest uniwersytet? Czy możemy zaobserwować podobne mechanizmy wyzysku i kontroli pracy? Czy uniwersytet może być skuteczną przestrzenią organizacji oporu, podobną do tej, jaką stanowiły fabryki ery industrialnej?

Dla Rauniga właśnie, podobnie jak dla kolektywu Edu-factory, najistotniejszym aspektem uniwersytetu pojmowanego jako fabryka są kwestie gromadzenia w nim przyszłych i aktualnych pracowników ${ }^{14}$. Skupienie się na fabrykach lub przestrzeniach mających potencjał stania-się-fabryką ma dla niego na celu nie tyle analizowanie dzisiejszego sposobu produkcji, co raczej skoncentrowanie się na walkach społecznych oraz procesach organizacji politycznej. W związku z tym interesuje go przede wszystkim okupowanie połączone z ponownym przyswajaniem przestrzeni tej instytucji ${ }^{15}$. Uniwersytet jest tutaj fabryką o tyle, o ile pozwala gromadzić różne rozproszone w epoce kapitalizmu kognitywnego podmioty pracownicze - które z racji luźnej relacji z kapitałem produkcyjnym nie mają zbyt wielu szans na zebranie się razem. Raunig pisze zatem, że „pełna ambiwalencja fabryki wiedzy w trybie modulacji, jej mechanizmów przyswajania oraz jej potencjału oporu, pozwala nam również na zrozumienie miejsc produkcji wiedzy nie tylko jako przestrzeni jej utowarowienia oraz wyzysku podmiotowości wszystkich aktorów, ale również i szczególnie jako miejsca nowych

11 G. Raunig, Factories of Knowledge, s. 40.

12 H. Cleaver, Praca w szkole i walka przeciwko pracy w szkole, tłum. A. Wila, „Przegląd Anarchistyczny” 2012, nr 13, s. 38-62.

13 Edu-factory: Samoorganizacja i opór w fabrykach wiedzy, red. J. Sowa, K. Szadkowski, Kraków 2011.

14 G. Raunig, Factories of Knowledge, s. 60.

15 Tamże, s. 21. Zob. również Fabryki i szkoty w czasach kryzysu. Dyskusja, „Przegląd Anarchistyczny” 2012, nr 13. 
form konfliktu"16. W warunkach kapitalizmu kognitywnego to szkoły i fabryki są miejscem, w którym koncentracja prekarnych robotników może się odbywać. To właśnie przede wszystkim pozwala na mówienie, że to, co kiedyś było fabryką, dziś jest uniwersytetem.

W powyższej opowieści brakuje jeszcze jednego ważnego ujęcia metafory fabryki stosowanej w kontekście uniwersytetu, na które uwagę zwrócił w swoim tekście Andrzej W. Nowak ${ }^{17}$. Chodzi mianowicie o bliskie jednemu z dwóch Marksowskich rozumień fabryki ujęcie jej sprawczego i technicznego potencjału poza kapitalistycznym zastosowaniem ${ }^{18}$. Fabryka w związku z tym rozumiana byłaby nie tyle jako alienująca i podporządkowująca sobie pracowników siła, ile rozwinięta postać zakumulowanych sił wytwórczych pracy i wiedzy, której można i należy nadać pozakapitalistyczne zastosowanie.

Moglibyśmy zatem w tym miejscu uporządkować przynajmniej trzy produktywne analitycznie strategie ${ }^{19}$ posługiwania się metaforą fabryki w kontekście uniwersytetu. Pierwsza strategia, nazwijmy ją „strategią subsumcji”, traktowałaby uniwersytet-fabrykę jako kluczowy sektor związany z rozwojem kapitalizmu kognitywnego, w którym praca byłaby poddana podporządkowaniu kapitałowi (formalnemu bądź realnemu). W związku z tym, przy użyciu metody krytyki ekonomii politycznej, poszukiwałaby mechanizmów, w oparciu o które kapitał rozwijałby i umacniał swoje panowanie w tym sektorze oraz procesy akumulacji, pomnażania i wydobywania wartości ${ }^{20}$. Druga strategia, którą moglibyśmy nazwać „strategią post-operaistyczną”, uznawałaby, że uniwersytet, analogicznie do przemysłowej fabryki pod względem topologii oporu, jest miejscem przestrzennej koncentracji rozproszo-

16 G. Raunig, Factories of Knowledge, s. 51.

17 A.W. Nowak, Demokratyzowanie czy neoluddyzm - reforma uniwersytetu wobec wyzwań technonauki, „Praktyka Teoretyczna” 2013, nr 1, s. 169-193.

18 K. Marks, Kapitat, t. 1, w: MED, t. 23, s. 476-477. Zob. również R. Panzieri, Capitalist use of Machinery: Marx Versus the Objectivists, w: Outlines of a Critique of Technology, red. P. Slater, London 1980, s. 120-141.

19 Wykluczam w tym miejscu wszelkie płaskie i obrazowe ujęcia publicystyczne podporządkowane przede wszystkim elitarystycznej wizji tej instytucji i straszące opinię publiczną masowością związaną z przemysłową produkcją wiedzy czy dyplomów. Tego typu narracja wspierana jest często przez kadrę akademicką czującą postępujące zagrożenie swojej pozycji.

20 Do przedstawicieli tego rodzaju odczytań możemy zaliczyć m.in Harry’ego Cleavera, Davida Harvie czy Alberto Toscano, zob. H. Cleaver, Praca w szkole; D. Harvie, Value-production and Struggle in the Classroom, "Capital and Class" 2006, no. 88, s. 1-32; A. Toscano, The Limits of Autonomy: Cognitive Capitalism and University Struggles, w: Cognitive Capitalism, Education and Digital Labor, red. M.A. Peters, E. Bulut, New York 2011, s. 259-274. 
nej i zbuntowanej intelektualności masowej, żywej wiedzy ${ }^{21}$. W polu zainteresowania tego typu lektury znajdowałyby się akty mobilizacji zachodzące w sektorze szkolnictwa wyższego. Wreszcie trzecią strategią byłaby „strategia alternatywy”, usiłująca skonceptualizować model przekraczający ograniczenia kapitalistycznego uniwersytetu przedsiębiorczego przy zachowaniu potencjału, który wytworzył22. Wychodzi ona z założenia, że jeśli uniwersytet zajmuje kluczowe miejsce we współczesnym systemie gospodarczym, to należy dla niego znaleźć niekapitalistyczne zastosowanie, które nie będzie zakładać powrotu do przedkapitalistycznej, feudalnej rzeczywistości. Uważam, że jedynie komplementarne posługiwanie się tymi perspektywami może przynieść analitycznie i politycznie płodne rezultaty.

\section{Molekularny aktywizm, czyli co łączy ruchy studenckie, Occupy Wall Street i strajkujących artystów?}

Kiedy udało nam się uchwycić motywacje, które kryją się za zainteresowaniem Rauniga uniwersytetami, możemy wreszcie przejść do właściwego tematu książki, łączącego ze sobą i przenikającego obie jej części.

Raunig wiele miejsca poświęca różnym formom protestów studenckich. Tym, co interesuje go najbardziej, jest „molekularny aktywizm”23, przekraczający granice polityki opartej na reprezentacji. Przy okazji swoich analiz wysuwa jednak kontrowersyjną tezę, głoszącą mianowicie, że jakościowo nowy etap w historii ruchów studenckich, a szerzej również ruchów społecznych po Seatlle w 1999 roku, nastąpił wraz z rozpoczęciem w kwietniu 2009 roku procesów demokratycznego przejmowania kontroli nad wydziałem nauk społecznych w chorwackim Zagrzebiu ${ }^{24}$. Kiedy przyjrzymy się chorwackiemu protestowi przez pryzmat filmu dokumentalnego Strajk na Filozofi ${ }^{5}$ sprawy wyglądają odrobinę inaczej. Widzimy wąką i tę samą grupę najbardziej aktywnych uczestników i uczestniczek

21 Odczytania w tym duchu to specyfika cytowanych G. Roggero, G. Rauniga czy kolektywu Edu-factory.

22 Zob. np. propozycje G. Roggero czy A.W. Nowaka.

23 G. Raunig, Factories of Knowledge, s. 72

24 Tamże. Szerzej o samym proteście zob. K. Szadkowski, Cata wtadza w ręce plenum!: Chorwacki ruch studencki i demokracja bezpośrednia $w$ dziataniu, „Przegląd Anarchistyczny" 2012, nr 13, s. 90-95, jak również opublikowany polski przekład Occupation Cookbook, Jak przeprowadzić okupację?: Okupacja Wydziatu Nauk Humanistycznych i Spotecznych w Zagrzebiu, „Przegląd Anarchistyczny” 2012, nr 13, s. 96 i n.

25 Strajk na Filozofii, reż. Igor Bezinović, Chorwacja 2012. 
biorących udział w decydujących momentach rozwojowych protestów, a demokratyczność wydarzenia zaczyna wyglądać niekiedy na wyreżyserowaną. Niemniej te zastrzeżenia nie oddalają argumentu, że w globalnej przestrzeni publicznej ruchów studenckich protesty w Chorwacji, jak również przyjęta przez nie forma stały się istotnym impulsem dla (ponownego) rozwoju form protestu nieopartych na reprezentacji. Czy będą to protesty okupacyjne w austriackim AudiMaxie, na Uniwersytecie Kalifornijskim, walka z podwyżką czesnego w Wielkiej Brytanii, czy również cała paleta ruchów Occupy, mających swoje korzenie w studenckim oporze i okupacjach. Wszystko to były istotne momenty wynajdywania nowych form instytucjonalności nie tylko dla ruchu studenckiego, ale i innych ruchów społecznych.

Antonio Negri, którego posłowie dołączono do książki ${ }^{26}$, widzi we wszystkich opisywanych przez autora procesach dążenia do objęcia kontrolą przestrzeni, w której mogłoby się uwspólnić i rozgrywać dotychczas zdefragmentowane prekarne życie. Na etapie „fabryki społecznej”, czy jak określa to Negri, w fazie realnej subsumcji społeczeństwa pod kapitał, walka toczy się nie tylko o kontrolę czasu pracy czy też o samo ponowne ustanowienie zatartej granicy między czasem pracy a czasem nie-pracy, ale również o miejsca, przestrzenie, w których wielość prekarnych pracowników może cieszyć się wolnym, autonomicznym współżyciem. Jeśli zawierzyć Marksowi i jego często przywoływanej przez Michaela Lebowitza koncepcji praktyki rewolucyjnej ${ }^{27}$, polegającej nie tylko na przemianie otaczających warunków społeczno -gospodarczych, ale również samych podmiotów, które miałyby rozpocząć życie w pokapitalistycznej rzeczywistości, to możemy wówczas upatrywać w tych zlokalizowanych praktykach oporu proces tworzenia „nowego człowieka”.

Ruchy prekariackie i ruchy Occupy, protesty artystyczne i studenckie wpisują się zatem według Rauniga w szerszą kategorię molekularnego aktywizmu, który jest częścią długiej genealogii ruchów cynicznych ${ }^{28}$. Współczesne ruchy posiadają zatem przynajmniej trzy godne uwagi aspekty: zajmują się wynajdowaniem nowych form wspólnotowego życia, opierają swoje organizacyjne formy na zasadzie radykalnego włączenia oraz kładą wyraźny nacisk na ponowne przyswojenie czasu ${ }^{29}$.

26 Zob. A. Negri, Countermelody, thum. G. Mecchia, w: G. Raunig, Factories of Knowledge, s. 161-165.

27 Zob. M.A. Lebowitz, The Socialist Alternative: Real Human Development, New York 2010.

28 G. Raunig, Factories of Knowledge, s. 150.

29 Tamże, s. 152.
Jeśli zawierzyć

Marksowi i jego często przywoływanej przez Michaela Lebowitza koncepcji praktyki rewolucyjnej, polegającej nie tylko na przemianie otaczających warunków społecznogospodarczych, ale również samych podmiotów, które miałyby rozpocząć życie w pokapitalistycznej rzeczywistości, to możemy wówczas upatrywać w tych zlokalizowanych praktykach oporu proces tworzenia „nowego człowieka” 
Sam nacisk na molekularną formę polityki, związaną z doświadczaniem życia codziennego, nie jest jednak w żaden sposób porzuceniem formy organizacji ${ }^{30}$. Jak twierdzi Raunig, „molekularne protesty są walkami, które wyłaniają się przypadkowo i rozszerzają się poprzez to, co akcydentalne. Jednak żaden pan nie przewodzi molekularnej organizacji”"31. Otwartość formy organizacyjnej, którą reprezentowało na przykład nowojorskie OWS, opierające się na włączeniu w demokratyczne podejmowanie decyzji w formie zgromadzenia ogólnego, miałaby stanowić podstawę pokapitalistycznej przyszłości. Prowadzone w jej ramach protesty są natomiast próbą zerwania z dominującym reżimem czasowości w celu stanowienia w przestrzeni nowych form wspólnego życia. Nie jest to zatem ekonomiczna walka o skrócenie czasu pracy, ale próba ustanowienia nowej czasowości.

\section{Alternatywy - w stronę instytucji dobra wspólnego}

Jeśli zatem uznać za Raunigiem uniwersytet za istotny punkt odniesienia dla prekariackiego oporu, miejsce-węzeł skupiający rozproszoną siłę roboczą, to musimy zadać sobie pytanie o to, jakiego rodzaju alternatywy można zbudować w oparciu o i w odniesieniu do uniwersytetu?

Podobnie jak w wypadku książki Roggero, również i tutaj mamy do czynienia z bardzo ograniczonym horyzontem. Na uznanie jednak zasługuje fakt samej próby konceptualnego zmierzenia się z myśleniem alternatywy dla uniwersytetu w jego obecnym kształcie ${ }^{32}$. Kluczowe znaczenie dla zrozumienia sposobu, w jaki Raunig myśli o alternatywach, miałaby operaistyczna topologia relacji między klasą robotniczą a kapitałem; owo znajdowanie się zawsze wewnątrz i przeciwko kapitałowi, posiadanie jednocześnie możliwości niedialektycznego zerwania tej relacji. A zatem fundamentalne znaczenie miałyby tu takie kategorie z tradycji post-operaistycznej, jak exodus czy odmowa pracy

30 Na tę kwestię słusznie wskazuje Bartosz Ślosarski, który posługując się teorią wielości Antonia Negriego i Michaela Hardta, w kontekście nowojorskiego ruchu Occupy w podobnym duchu co Raunig wskazuje na produktywne przekroczenie opozycji spontaniczność/organizacja w procesie politycznej mobilizacji i tworzenia warunków sprzyjających rozwojowi nowego życia wspólnotowego, który w 2011 roku zaszedł w Parku Zuccotti, zob. B. Ślosarski, Wielość między spontanicznością a organizacja. Organizacyjna forma nowych ruchów spotecznych, materiały pokonferencyjne „Kultura kontestacji - Dziedzictwo kontrkultury i nowe ruchy społecznego sprzeciwu", 20-21 XI 2013 (w druku).

31 G, Raunig, Factories of Knowledge, s. 153.

32 Tamże, s. 66. 
jako praktyki konstytuujące. Raunig dzieli strategie oporu w odniesieniu do uniwersytetu na, z jednej strony, mikropolityczne praktyki rozwijania kruchych form autonomii w obrębie instytucji, z drugiej zaś, deterytorializację i reterytorializację produkcji wiedzy na zewnątrz uniwersytetu czyli tworzenie alternatywnych form jej produkcji. Wśród strategii pierwszego typu Raunig wymienia m.in. odmowę wywierania presji na osobach znajdujących się niżej w instytucjonalnej hierarchii, hakowanie systemu pomiaru przez przyznawanie punktów za wydarzenia wykraczające poza logikę danej instytucji, bojkot systemu recenzji i czasopism punktowanych, eksperymentowanie z formami publikacji czy przejmowanie kontroli nad przestrzenią instytucjonalną poprzez okupacje. Wśród strategii drugiego typu znajdziemy: kolektywy produkujące lokalną i usytuowaną, powiązaną z walkami społecznymi wiedzę, alternatywne media, czy transnarodowe maszyny abstrakcyjne, którym to mianem Raunig nazywa projekty w rodzaju Edu-factory. Są to procesy tworzenia nowych fabryk i powstawania nowych trybów produkcji wiedzy opartej na nieposłuszeństwie. Raunig gra dalej byciem wewnątrz i przeciwko. Według niego należy do pewnego stopnia żerować na zasobach instytucji, w związku z tym niekoniecznie punktem wyjścia musi być relacja zerwania. Przypomina to w pewnym sensie „pod-wspólności”, o których pisali Harney i Moten ${ }^{33}$. Jednak należy zaznaczyć, że nie chodzi mu tylko o zacieranie granic między wnętrzem a zewnętrzem instytucji, co raczej o czasowe nakładanie się na siebie tych kontekstów, pewnej wymiany zachodzącej między nimi. W ten sposób miałby dochodzić do tworzenia organów transwersalnego intelektu ${ }^{34}$, formy produkcji wiedzy przekraczającej stare modele awangardy czy zrzeszeń organicznych intelektualistów ${ }^{35}$.

Należy przyznać, że post-operaistyczne modele alternatywy i oporu formułowane w kontekście uniwersytetu posiadają liczne ograniczenia. W ramach autonomicznych i opartych na dezercji/exodusie modeli produkcji wiedzy, które służą teoretykom tej tradycji za punkty odniesienia, ciężko jest sobie wyobrazić funkcjonowanie nauk ścisłych czy biologiczno-medycznych, angażujących w procesie innowacji, oprócz sił intelektu, ogromne ilości zasobów. Należy również zwrócić uwagę na to, że sam kolektywny wymiar praktyki produkcyjnej wiedzy jest w tych dziedzinach już obecny w dużo większym stopniu niż w na-

33 S. Harney, F. Moten, Uniwersytet i podwspólność, tłum. P. Kowzan, M. Zielińska, http://www.ha.art.pl/prezentacje/39-edufactory/1815-stefano-harney-fredmoten-uniwersytet-i-podwspolno.html.

34 G. Raunig, Factories of Knowledge, s. 68.

35 Tamże, s. 67. 
Przydatne zatem byłoby wykroczenie poza model oparty wyłącznie na exodusie

i poszukiwanie pozytywnej wizji niekapitalistycznego (poza tym, co prywatne

i tym, co publiczne) zarządzania instytucją uniwersytetu ukach humanistycznych, które często służą za podstawowe odniesienie post-operaistów. Przydatne zatem byłoby wykroczenie poza model oparty wyłącznie na exodusie i poszukiwanie pozytywnej wizji niekapitalistycznego (poza tym, co prywatne i tym, co publiczne) zarządzania instytucją uniwersytetu. Ale czy niekapitalistyczne wykorzystanie fabryk wiedzy jest możliwe w warunkach kapitalistycznej gospodarki i społeczeństwa? W jednym z popularnych w trakcie kalifornijskich okupacji uniwersytetów manifeście pisano: „wolny uniwersytet w środku kapitalistycznego społeczeństwa jest jak czytelnia w więzieniu" ${ }^{36}$. Trudno lepiej oddać klincz, w jakim znajdują się wspótczesne próby myślenia alternatywy dla subsumowanego pod kapitał uniwersytetu.

\section{Horyzont możliwości}

Właśnie na to ograniczenie, w kontekście narastającej fali protestów studenckich, pod koniec lat sześćdziesiątych zwrócił uwagę Ernst Mandel pisząc, że „w dłuższej perspektywie uniwersytet jako instytucja pozostaje uwiązany złotymi łańcuchami do władzy klasy panującej. Bez radykalnej transformacji społeczeństwa jako całości uniwersytet nie może przejść żadnej "trwałej« radykalnej transformacji”37. Ta trzeźwa konstatacja jest dziś aktualna bardziej niż kiedykolwiek. Jednak należałoby przemieścić ją z poziomu analizy stosunków władzy, gdzie uniwersytet jest jednym z ideologicznych aparatów państwa, na poziom produkcji, rozumiejąc go jako instytucję wytwórczą, instytucję dobra wspólnego. Dziś bowiem jest on przede wszystkim integralną częścią kapitalistycznego sposobu produkcji opartego o pomnażanie wartości wiedzy i produkcję podmiotowości, i bez transformacji tego sposobu produkcji również i w jego ramach niemożliwa jest jakakolwiek trwała transformacja. Mandel jednakże nie poprzestawał na powyższej diagnozie, twierdził bowiem, że „to, co jest niemożliwe dla uniwersytetu jako instytucji, możliwe jest dla studentów jako jednostek i grup. A to, co możliwe jest dla studentów jako jednostek i grup, może, na poziomie zbiorowym, tymczasowo wyłonić się jako możliwość dla uniwersytetu jako całości”38. To właśnie w ramach bycia wewnątrz uniwerste-

36 Research and Destroy, Communiqué z nieobecnej przysztości - o kresie życia studenckiego, tłum. K. Szadkowski, M. Szlinder, „Praktyka Teoretyczna” 2010, nr 1, s. 190-203.

37 E. Mandel, The Changing Role of the Bourgeois University, http://www. marxists.org/archive/mandel/1970/06/university.htm.

38 Tamże. 
tu i przeciwko niemu, w tworzeniu odmiennych sposobów transmisji i produkcji wiedzy, w kolektywnym wytwarzaniu nowych i zakorzenionych w oporze form wspót-bycia rodzi się alternatywa dla kapitalistycznego, uniwersyteckiego status quo. Instytucje dobra wspólnego tworzone w ramach zarówno studenckiej, jak i szerszej walki społecznej kładą podstawy pod ten horyzont możliwości, na którego istotność nieustannie w swojej książce zwraca nam uwagę Raunig. Jednak podążanie w stronę tego otwartego horyzontu to kwestia, którą winniśmy pozostawić praktyce ${ }^{39}$.

39 W trakcie pisania korzystałem ze wsparcia płynącego z grantu MAESTRO - Narodowego Centrum Nauki - DEC-2011/02/A/HS6/00183 (2012-2017).

To właśnie w ramach

bycia wewnątrz

uniwerstetu i przeciwko niemu, w tworzeniu odmiennych sposobów transmisji i produkcji wiedzy, w kolektywnym wytwarzaniu nowych i zakorzenionych w oporze form współ-bycia rodzi się alternatywa dla kapitalistycznego, uniwersyteckiego status quo 
KRYSTIAN SZADKOWSKI - doktorant w Instytucie Filozofii UAM. Zajmuje się problematyką szkolnictwa wyższego i kapitalizmu kognitywnego oraz ich wzajemnych relacji.

\section{Dane adresowe:}

Instytut Filozofii UAM

ul. Szamarzewskiego 89a

60-568 Poznań

e-mail: szadkowski.k@gmail.com

\section{Cytowanie:}

K. Szadkowski, Uniwersytet jako przestrzeń modulacji i molekularnego oporu., „Praktyka Teoretyczna” nr 3(9)/2013, http://www.praktykateoretyczna. pl/PT_nr9_2013_Po_kapitalizmie/15.Szadkowski.pdf (dostęp dzień miesiąc rok) 